\title{
Land suitability analysis for agriculture in the Abbay basin using remote sensing, GIS and AHP techniques
}

\author{
Seleshi G. Yalew ${ }^{1,2} \cdot$ Ann van Griensven ${ }^{1,3} \cdot$ Marlous L. Mul ${ }^{4} \cdot$ Pieter van der Zaag ${ }^{1,5}$
}

Received: 30 April 2016/ Accepted: 4 June 2016/Published online: 15 June 2016

(C) Springer International Publishing Switzerland 2016

\begin{abstract}
To meet growing population demands for food and other agricultural commodities, agricultural land-use intensification and extensification seems to be increasing in the Abbay (Upper Blue Nile) basin in Ethiopia. However, the amount, location and degree of suitability of the basin for agriculture seem not well studied and/or documented. From global data sources, literature review and field investigation, a number of agricultural land suitability evaluation criteria were identified. These criteria were preprocessed as raster layers on a GIS platform and weights of criteria raster layers in determining suitability were computed using the analytic hierarchy process (AHP). A weighted overlay analysis method was used to compute categories of highly suitable, moderately suitable, marginally suitable and unsuitable lands for agriculture in the basin. It was found out that $53.8 \%$ of the basin's land coverage was highly suitable for agriculture and $23.2 \%$ was moderately suitable. The marginally suitable and the unsuitable lands were at 11 and $12 \%$ respectively. From the analysis, regions of the basin with high suitability as well as those with higher susceptibility for land degradation and soil erosion were identified.
\end{abstract}

Seleshi G. Yalew

s.yalew@unesco-ihe.org

1 UNESCO-IHE Institute for Water Education, 2601 DA Delft, The Netherlands

2 Farming Systems Ecology Group, Wageningen University, Wageningen, The Netherlands

3 Vrije Universiteit Brussel, Brussels, Belgium

4 International Water Management Institute-IWMI, Accra, Ghana

5 Water Resources Section, TU Delft, Delft, The Netherlands
Keywords Blue Nile · AHP · Multi-criteria analysis . Suitability $\cdot$ Weighted overlay

\section{Introduction}

Increasing population and associatively growing demand for food and other agricultural commodities have caused an intensification and extensification of the agricultural sector witnessed in the last decade (Lambin and Meyfroidt 2011; Tscharntke et al. 2012; Rudel et al. 2009). As an agriculture dominated basin in Ethiopia, the Upper Blue Nile seems to be experiencing similar pleasures (Gebrehiwot et al. 2014; Bewket and Sterk 2002). However, the amount, location and degree of suitability of the basin for agriculture do not seem well studied and/or documented. Haphazard land-use has thus far resulted in continuing deforestation, exhausted soil fertility, increased soil erosion and land degradation especially in the basin's highland catchments (Zeleke and Hurni 2001; Bewket 2002; Awulachew et al. 2010). Land suitability analysis can help establish strategies to increase agricultural productivity (Pramanik 2016) by identifying inherent and potential capabilities of land for intended objectives (Bandyopadhyay et al. 2009). It can also help identify priority areas for potential management and/or policy interventions through land and/or soil restoration programs, for instance.

The analytical hierarchy process (AHP) (Saaty 1980) technique integrated with GIS application environments has been used for agricultural land suitability analysis on various case study sites around the world (Zabihi et al. 2015; Akınc1 et al. 2013; Zolekar and Bhagat 2015; Pramanik 2016; Malczewski 2004). It involves pair-wise and weighted multi-criteria analysis on a number of selected socio-economic and biophysical drivers. The technique has 


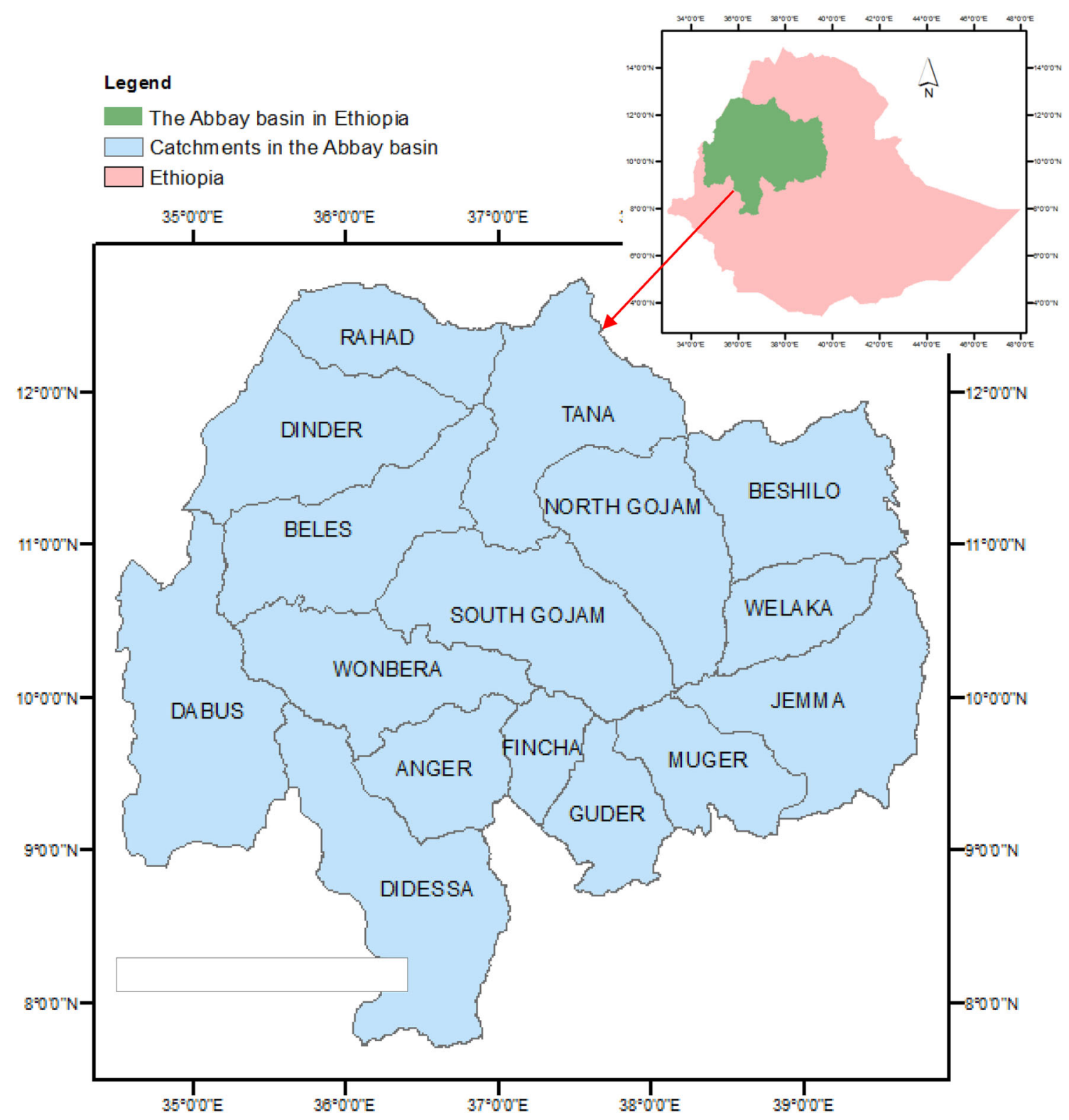

Fig. 1 Location map of the Abbay basin and its catchments in Ethiopia

extensively been used for land suitability analysis at local and region levels for watershed planning (Steiner et al. 2000), vegetation (Zolekar and Bhagat 2015) and agriculture (Shalaby et al. 2006; Bandyopadhyay et al. 2009; Akınc1 et al. 2013; Motuma et al. 2016). Biophysical parameters such as land cover, slope, elevation, and soil properties such as depth, moisture, texture and group are frequently used for assessment of land suitability evaluation (Rossiter 1996; Zolekar and Bhagat 2015). 'Expert opinion' is used for weighting such factors in influencing land suitability through pair-wise comparison in AHP.

In this study, we analyzed agricultural land-use suitability in the Abbay basin using AHP and GIS based weighted overlay analysis (WOA) techniques. Multiple criteria for agricultural land-use suitability mapping were derived based on literature reviews, field investigations and following FAO guidelines for agricultural land-use evaluation (Rossiter 1996; Zolekar and Bhagat 2015; Zabihi et al. 2015; Bandyopadhyay et al. 2009). Identification and mapping of agricultural land suitability is especially important in the basin given the following considerations: (1) the pressing need to increase agricultural productivity to meet growing food demands, (2) the growing risks of increased rainfall variability due to climate change in already water limited agricultural systems, and (3) the growing interest by local and regional policy and management bodies for evaluation of land capability for various land-use alternatives. 
Table 1 Data and data sources

\begin{tabular}{lll}
\hline Data & Spatial resolution & Source \\
\hline Elevation & $30 \mathrm{~m}$ & SRTM (GEE) \\
Slope & $30 \mathrm{~m}$ & Computed from SRTM \\
Soil type & $5 \mathrm{arc} \mathrm{min}$ & FAO (FGGD) (2013) \\
Soil depth & $5 \mathrm{arc} \mathrm{min}$ & FAO (2014) \\
Soil stoniness & $1 \mathrm{~km}$ & ISRIC-worldgrid 1 km (2014) \\
Soil water content & $30 \mathrm{arc} \mathrm{s}$ & CGIAR-CSI (2010) \\
Towns & Woreda (county) level & CSA (2007), FAO \\
Roads & All weather roads & CSA (2007), FAO \\
River/water bodies & Perennial streams & MoWR, Ethiopia \\
Protected areas & 2.5 arc min & IUCN \& UNEP-WCMC (2012) \\
Land cover & $300 \mathrm{~m}$ & ENVISAT/MERIS (Bontemps et al. 2011) \\
\hline
\end{tabular}

${ }^{a}$ Google Earth Engine

Fig. 2 Process diagram of the methods used in the stud

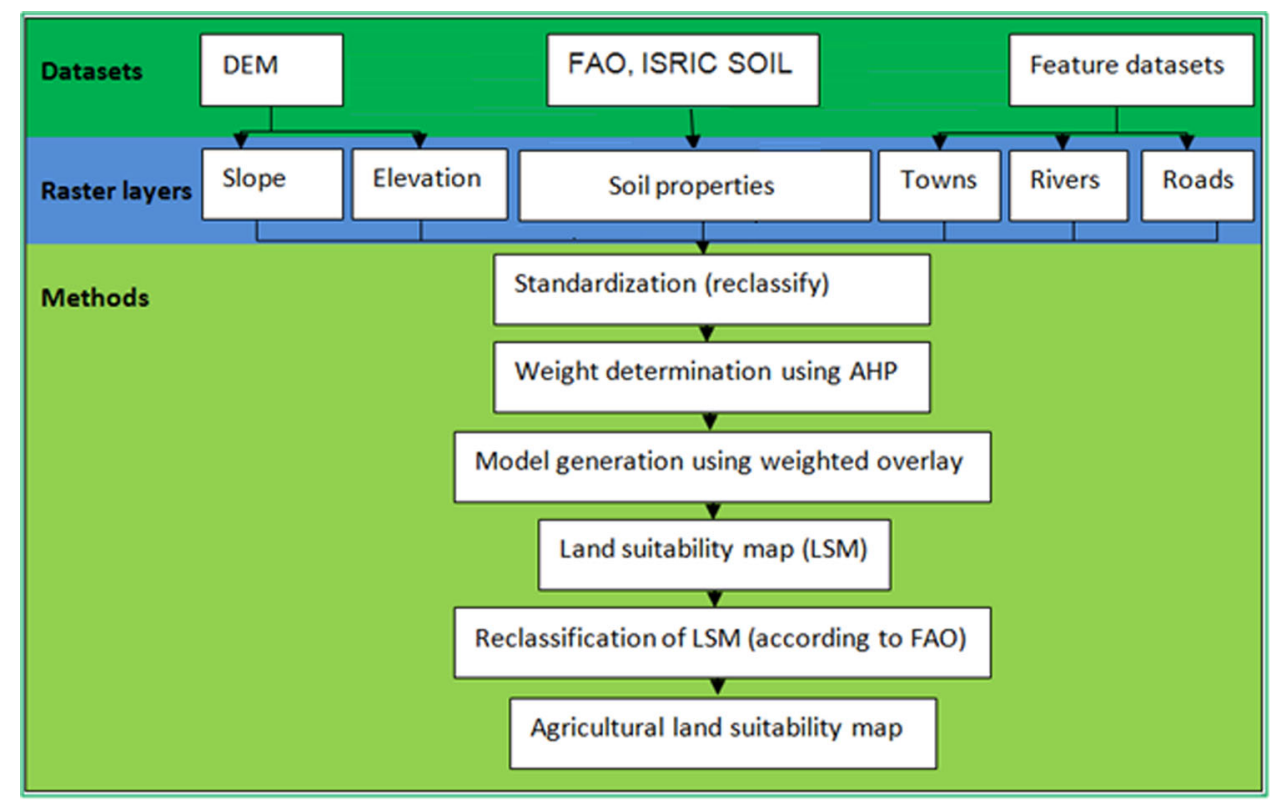

Located on the western half part of Ethiopia (Fig. 1), Abbay is the most important river basin in Ethiopia by most criteria. It accounts for about $20 \%$ of the nation's land area; $50 \%$ of its total average annual runoff; $25 \%$ of its population; and over $40 \%$ of its agricultural production (EEPCo 2014). Divided into 16 major catchments (Fig. 1), the basin covers an area of $199,812 \mathrm{~km}^{2}$ with significant contribution of runoff and fertile highland soil to Sudan and Egypt in the downstream. Biophysical and anthropogenic factors combined with torrential runoffs in the rugged highlands in the basin are causing considerable land degradation and soil erosion in the upstream, whereas deforestation is a major concern in the mid/low lands of the basin (Hurni et al. 2005; Gebrehiwot et al. 2014). Torrential runoff washing off the rugged terrains, poor land-use management has been reported as a cause for gully formation, soil erosion and land degradation threaten the livelihood of subsistence farmers (Teferi et al. 2012; Yalew et al. 2012; Tekleab et al. 2014).

\section{Materials and methods}

Using literatures and guidelines on land evaluation for agriculture (Bojórquez-Tapia et al. 2001; Prakash 2003; Bandyopadhyay et al. 2009; Wang 1994; Olaniyi et al. 2015; Zhang et al. 2015; Rossiter 1996) we identified nine important criteria that determine agricultural land suitability in the basin: soil type, soil depth, soil water content, soil stoniness, slope, elevation and proximity to towns, roads and water sources (Table 1). GIS raster datasets on each of these indicators were gathered and processed from 


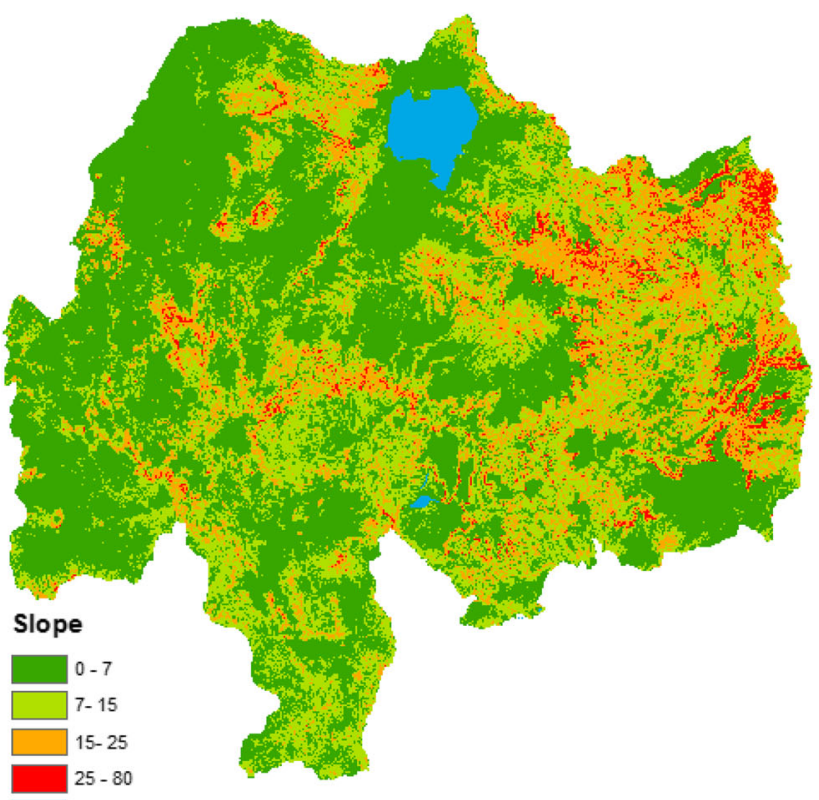

(a)

Fig. 3 a Slope and $\mathbf{b}$ elevation maps of the Abbay basin

Table 2 Slope classes for agricultural suitability

\begin{tabular}{ll}
\hline Slope class $\left(^{\circ}\right)$ & Suitability score \\
\hline $0-7$ & 4 \\
$7-15$ & 3 \\
$15-25$ & 2 \\
$>25$ & 1 \\
\hline
\end{tabular}

several sources for the study areas. According to FAO guidelines (Rossiter 1996), land suitability for agriculture can be classified into five categories: (1) highly suitable, (2) moderately suitable, (3) marginally suitable, (4) currently unsuitable and (5) permanently unsuitable. In this study, we customized and reclassified each raster criteria layer into four categories with associated suitability score of $1-4 \quad(4=$ highly suitable; $3=$ moderately suitable; $2=$ marginally suitable; and $1=$ unsuitable). The 'unsuitable' category represents the 'permanently unsuitable' category of FAO. Similar to what is defined as 'currently unsuitable' in the FAO method, we excluded forest and protected areas from the suitability computation altogether assuming that such land may not be used (and hence 'unavailable') for agriculture in favor of other ecological services (biodiversity conservation). Weights for each of the selected criterion were calculated using the AHP technique. After the weight of each raster dataset was computed, a GIS based WOA was carried out to establish a suitability map. The process diagram of the method used is shown in Fig. 2.

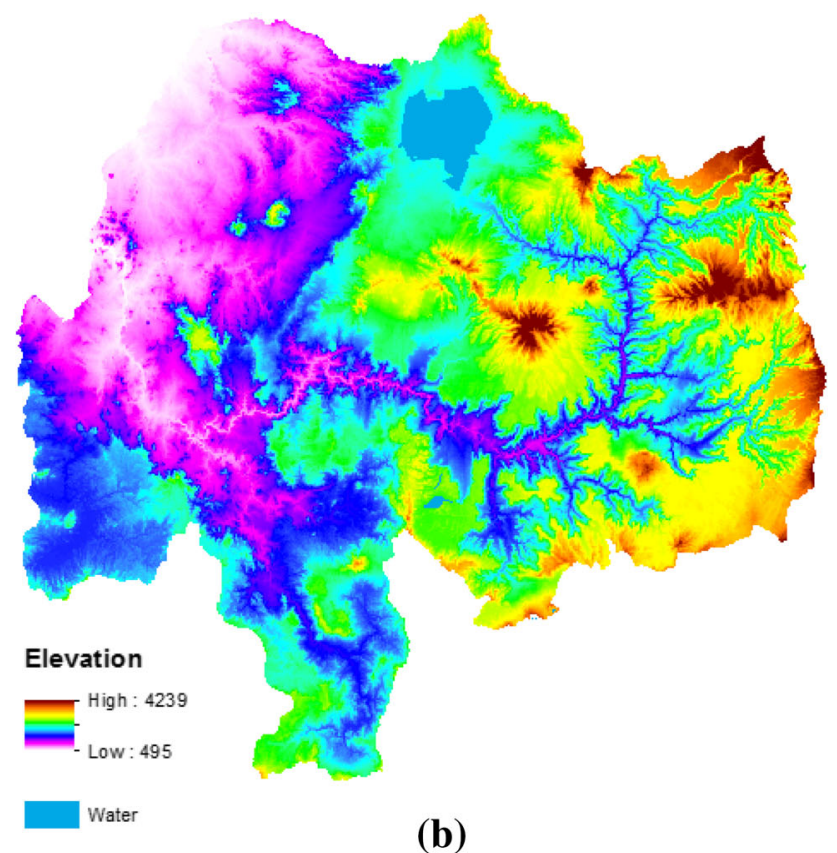

\section{Generation of criteria maps}

\section{Slope and elevation}

Slope and elevation data layers (Fig. 3a, b), respectively) were generated from the Shuttle Radar Topography Mission (SRTM) digital elevation model (DEM) data of $30 \mathrm{~m}$ resolution available on the Google Earth Engine archive (Moore and Hansen 2011; Gorelick 2013). Based on FAO manual for agricultural watershed management (Sheng 1990), agricultural suitability of different slope classes for the study area are defined as in Table 2. However, since no specific crop suitability is assumed, elevation value lower than $3700 \mathrm{~m}$ a.s.l. is taken to be suitable for agriculture. Elevation above $3,700 \mathrm{~m}$ is classified as 'high wurch' (frosty-alpine) and thus unsuitable for agricultural purposes according to the agro-ecological zoning of Ethiopia (FAO 2003).

\section{Soil properties}

Soil characteristics are one of the most important factors in agricultural land-use assessment (Dominati et al. 2016; Bonfante and Bouma 2015; Juhos et al. 2016). In this study, soil depth, soil water content, soil type and soil stoniness are taken as indicators to assess general soil suitability for agriculture. Soil depth and averaged soil water content maps are shown in Fig. 4. Soil type and soil stoniness are shown in Fig. 5. The soil properties used here were standardized for land suitability assessment as shown 


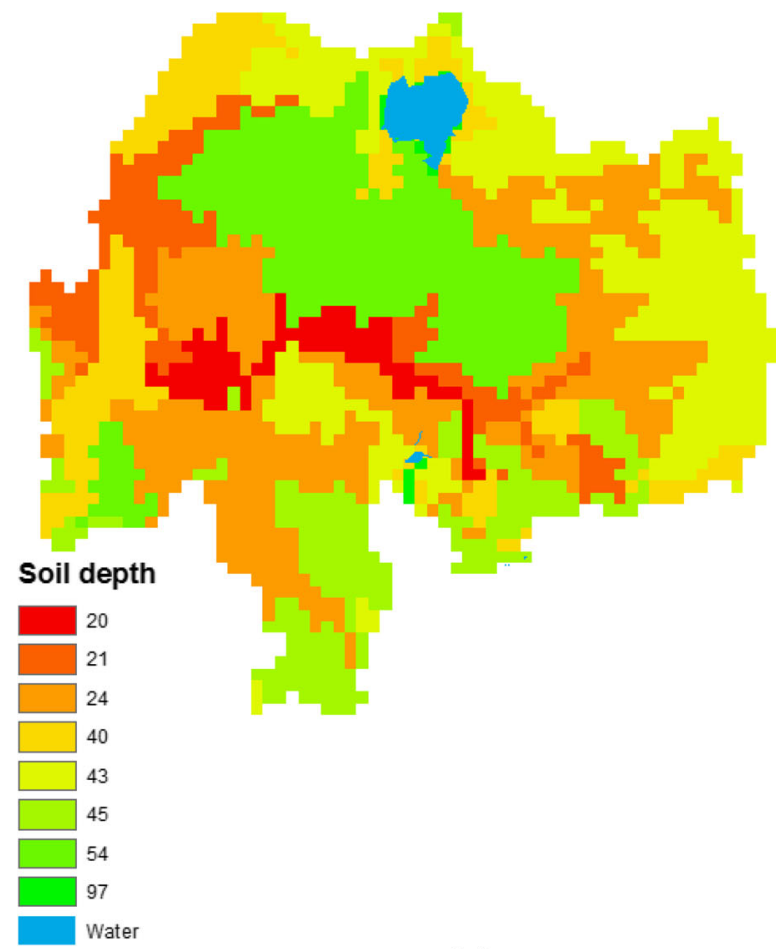

(a)

Fig. 4 a Soil depth and b soil water content in the Abbay basin

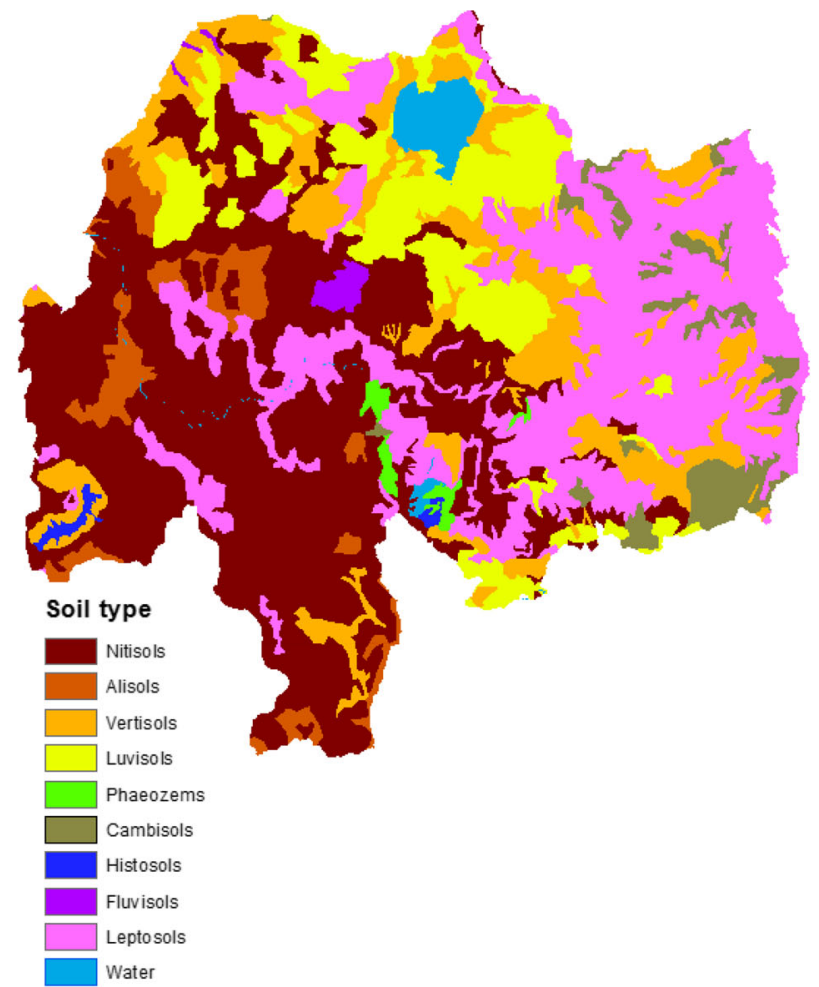

(a)

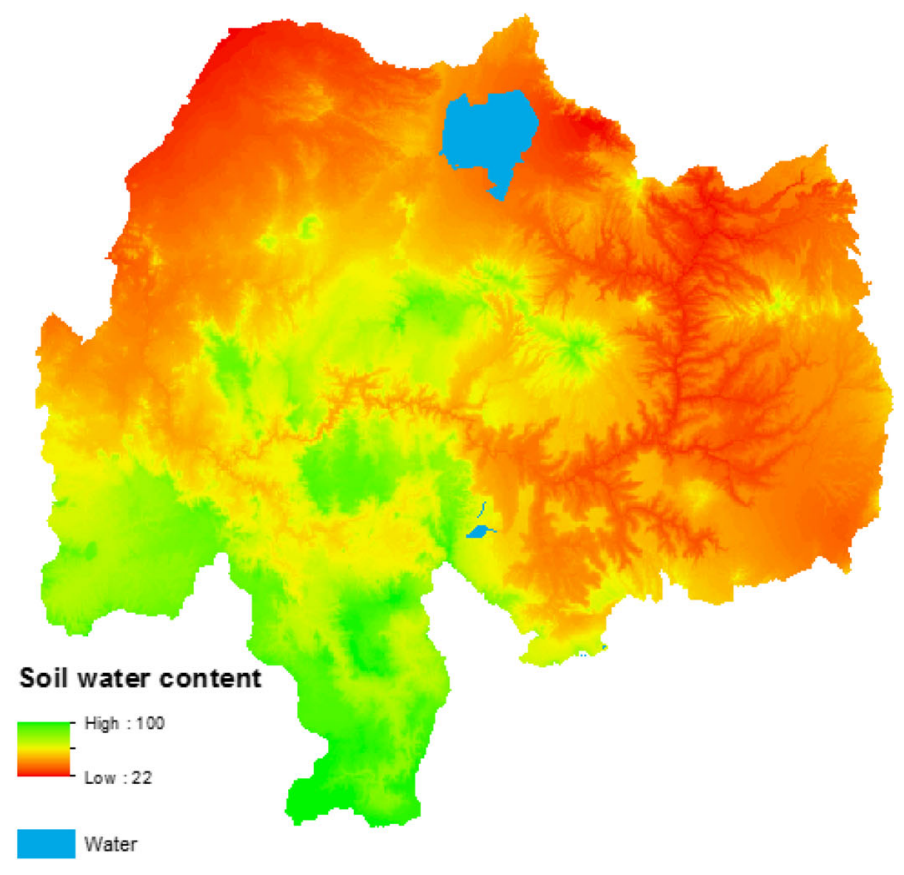

(b)

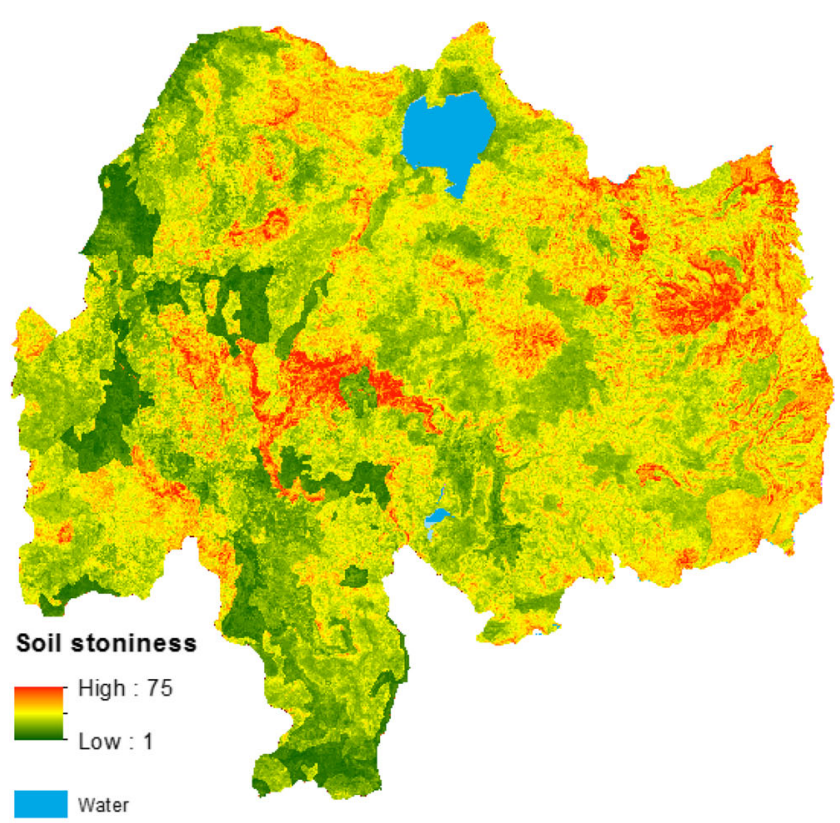

(b)

Fig. 5 a Soil types and $\mathbf{b}$ soil stoniness in the Abbay basin 
Table 3 Soil characteristics and suitability for agriculture

\begin{tabular}{lllll}
\hline Soil property & \multicolumn{2}{l}{ Suitability score } & \\
\cline { 2 - 4 } & 4 & 3 & 2 & 1 \\
\hline Soil depth $(\mathrm{cm})$ & $<90$ & $50-90$ & $20-50$ & $0-20$ \\
Soil stoniness $(\%)$ & $0-3$ & $3-15$ & $15-50$ & $>50$ \\
Soil type & NS, LS, CS, PS & VS, AS & HS, LpS & - \\
Soil water content $(\%)$ & $90-100$ & $70-90$ & $30-70$ & $<30$ \\
\hline
\end{tabular}

in Table 3. These soil characteristics were categorized based on the soil classification and characterization guide for agricultural suitability by FAO (Sheng 1990), and other guidelines for common biophysical criteria for defining natural constraints for agriculture (Van Orshoven et al. 2012).

Soil stoniness refers to percentage of gravel/stone content within the top $90 \mathrm{~cm}$ soil depth. Soil groups were classified based on their suitability and limitations for agriculture as outlined by FAO and the international livestock research institute (LRI) (1992). Based on the guides, the major soils in the study area are classified as:

- Soils with very high potential: nitisols (NS), luvisols (LS), cambisols (CS), phaeozems (PS).

- Soils with few limitations for agriculture: vertisols (VS), alisols (AS).

- Soils with major limitations (low production potential, rocky terrain soils, poorly drained soils): histosols (HS), liptosols (LpS).

Soil water content dataset was derived from the spatially distributed soil-water balance model by Trabucco and Zomer (2010). In their model, Trabucco and Zomer simulated a soil-water balance model for the years from 1950 to 2000 as a height of water (in $\mathrm{mm}$ ) per month (m) using Eq. (1):

$\Delta S W C_{m}=E P r_{e c}-\Delta A E T_{m}-R_{m}$

where, $\Delta S W C_{m}$ is the change in soil water content, $E P r_{e c}$ is the effective precipitation, $\triangle \mathrm{AET} T_{m}$ is the actual evapotranspiration, and $R_{m}$ is the runoff component which includes both surface runoff and subsurface drainage. Furthermore, $S W C_{m}$ may not exceed $S W C_{\max }$, which is the total maximum soil water content (SWC) available in the soil for evapotranspiration. $S W C_{\max }$ was assumed by the modelers at a fixed spatial value of $350 \mathrm{~mm}$, which corresponds to average soil texture for a plant rooting depth of $2 \mathrm{~m}$. The soil water content was then computed as a linear percentage function of actual and potential (maximum) soil water content over the months and the years from 1950 to 2000 as shown with Eq. (2):

$\operatorname{Ksoil}_{m}=\sum_{k=1}^{y}\left(\sum_{k=1}^{12}\left(S W C_{m} / S W C_{\text {max }}\right)\right)$
Where, $\mathrm{Ksoil}_{m}$ is percentage of average soil water content, $S W C_{m}$ is actual soil water content in month (m), $S W C_{\max }$ is the maximum (potential) soil water content, and y is year.

\section{Proximity to water, road and towns}

Spatial proximities to water sources, road and towns (Fig. 6a-c, respectively) were computed using spatial overlay of respective GIS layers. Influences of distance parameters on agricultural land suitability, Table 4, were estimated based on literature and field observation (Wale et al. 2013; Bizuwerk et al. 2005).

In addition to the criteria inputs for agricultural land suitability assessment discussed thus far, data on land cover and protected sites where collected for overlay analysis to serve as constraint layers on the final suitability map. Land cover map (Fig. 7a) was derived and reclassified from GlobCover2009. GlobCover2009 is a global land cover map based on ENVISAT's Medium Resolution Imaging Spectrometer (MERIS) Level 1B data acquired in full resolution mode with a spatial resolution of $300 \mathrm{~m}$ (Bontemps et al. 2011). Map on protected sites (Fig. 7b) which includes areas such as national parks and reserve sites was derived from the 'Protected Sites' global dataset of UNEP's World Conservation Monitoring Centre (UNEPWCMC 2012).

We assumed that forest, protected areas and water bodies as unavailable (and hence 'currently unsuitable') for agriculture. Changes in policy or management could easily change the suitability of these layers. A forest may, for instance, be deforested for large scale agriculture and thus changing its land suitability. These layers (Fig. 8) are therefore used as constraints that are superimposed on top of the computed suitability map.

\section{Standardization of criteria maps}

The selected criteria maps are initially in different units. For executing WOA for land suitability, the criteria maps need to be converted into a similar scale through standardization techniques. Standardization techniques convert the measurements in each criteria map into uniform measurement scale so that the resulting maps lose their 


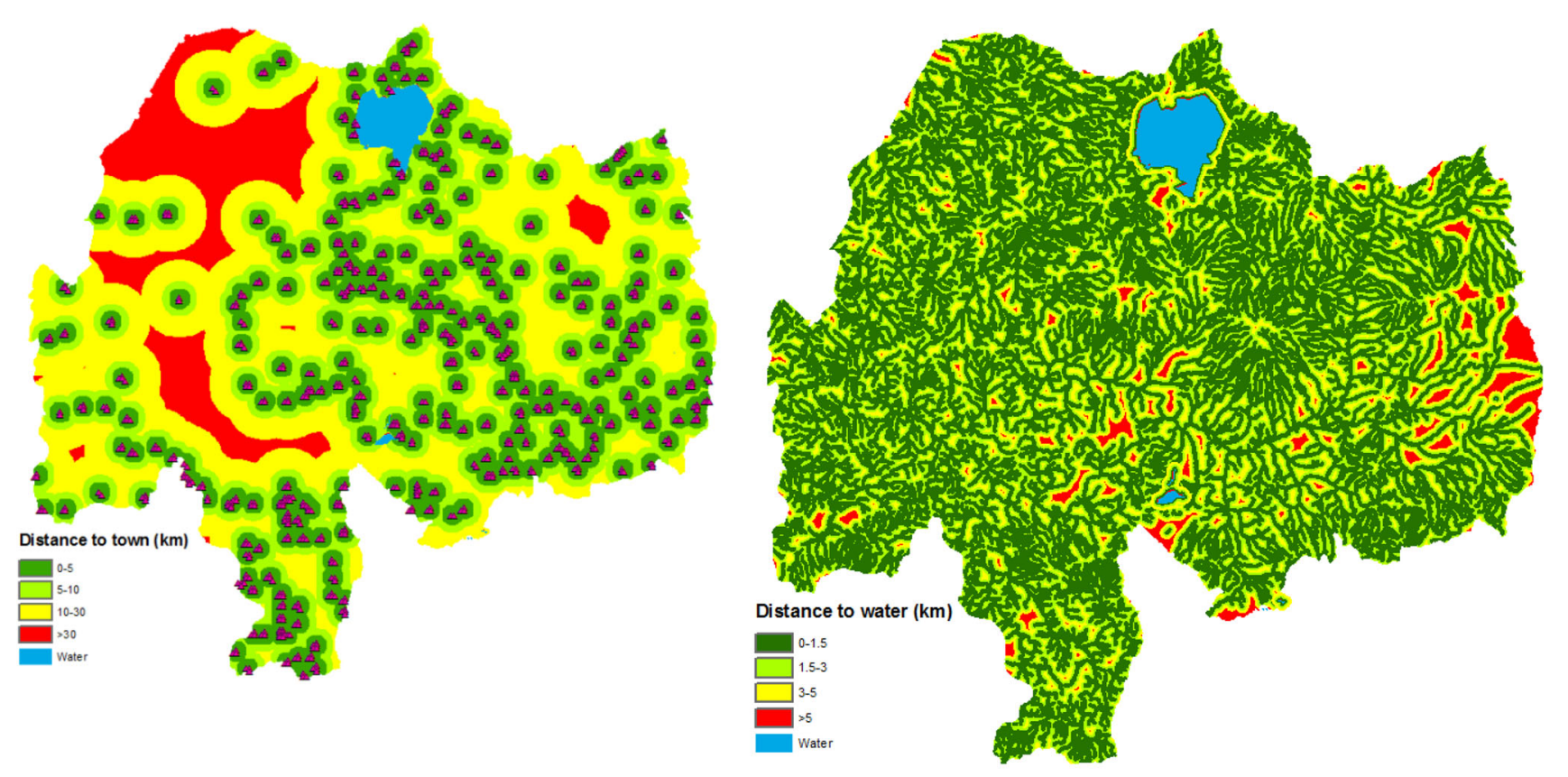

(a)

(b)

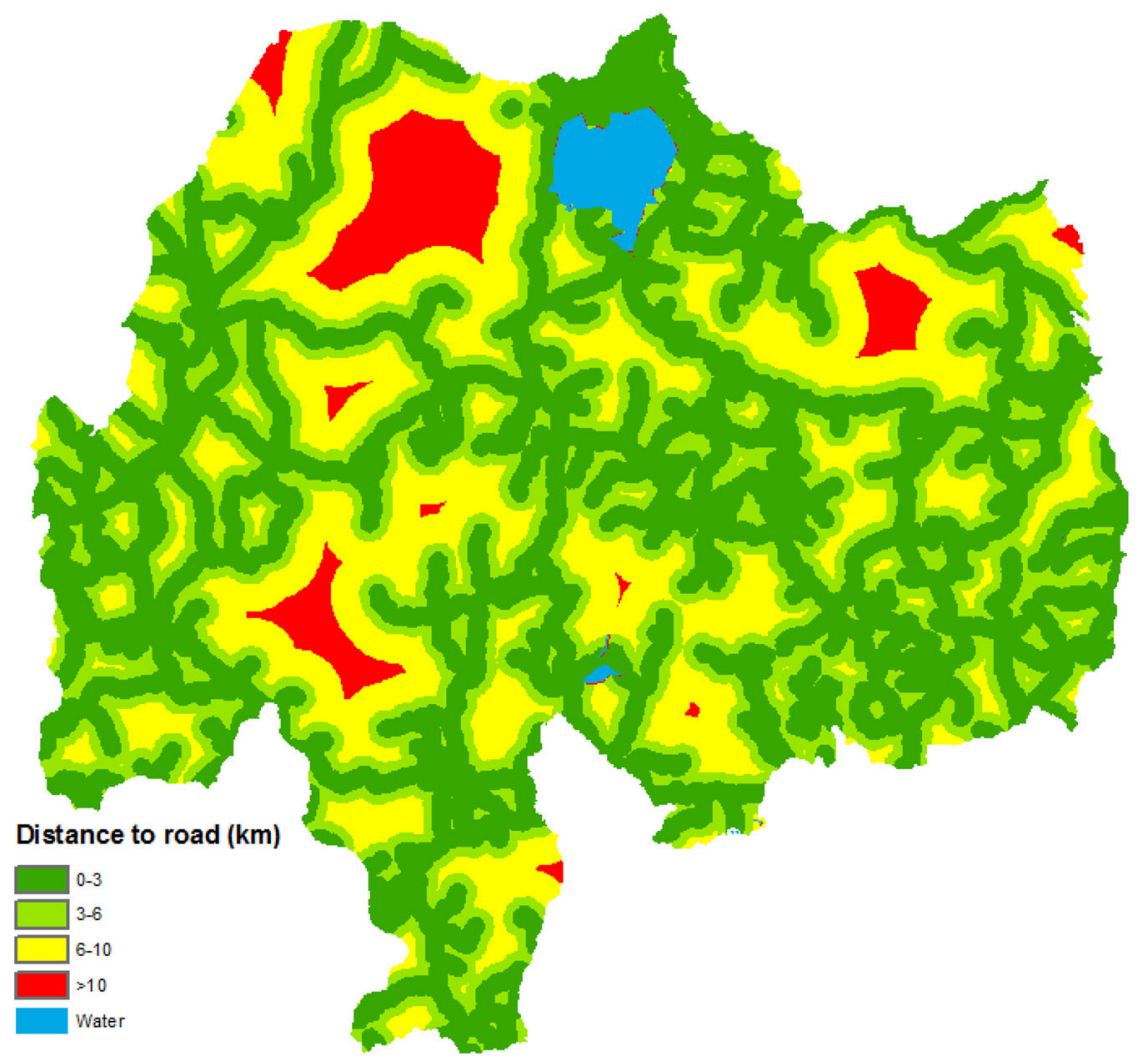

(c)

Fig. 6 Distances to a town, b water sources and $\mathbf{c}$ road in the Abbay basin 
Table 4 Proximity influences on agricultural land suitability

\begin{tabular}{lllll}
\hline Proximity $(\mathrm{km})$ & \multicolumn{5}{l}{ Suitability score } \\
\cline { 2 - 5 } & 4 & 3 & 2 & 1 \\
\hline Distance to town & $0-5$ & $5-10$ & $10-30$ & $>30$ \\
Distance to roads & $0-3$ & $3-6$ & $6-10$ & $>10$ \\
Distance to water & $0-1.5$ & $1.5-3$ & $3-5$ & $>5$ \\
\hline
\end{tabular}

dimension along with their measurement unit (Reshmidevi et al. 2009; Zabihi et al. 2015). For standardization, all the criteria vector maps were converted to raster data formats. The raster maps were then reclassified using the Spatial Analyst tool in ArcMap into four comparative categories as discussed earlier: highly suitable, moderately suitable, marginally suitable and unsuitable. Once all the criteria maps are standardized, weights of each criteria map can be calculated using AHP. Then WOA method will be applied to produce the final suitability map.

\section{Calculation of weight for criteria maps}

The analytic hierarchy process (AHP) is used to calculate weights for the criteria maps. It is a structured method for analyzing complex decisions by breaking them into pairwise alternatives of two at a time (Saaty 1988, 2008). It involves sub-dividing big and intangible decision problems into minute sub-problems amenable for pair-wise comparison (Saaty 1987). An AHP plugin tool for the ArcGIS environment (Marinoni 2009) was used to compute weights for the different criteria layers. Using the pair-wise comparison matrix, the analytic hierarchy process calculates comparative weights for individual criterion layers. It also produces consistency ratio (CR) that serves as a measure of logical inconsistency of expert/user judgments during pair-wise criteria comparisons, measured using Eq. (3).

$\mathrm{CR}=\frac{C I}{R I}$

where, $C I$ represents consistency index, and $R R$ represents random index.

The CR measurement facilitates identification of potential errors and thus judgment improvements depend on these values. According to Saaty (1988), if the CR value is much in excess of 0.1 , the judgments during pair-wise comparison are untrustworthy because they are too close for randomness. Saaty (1988) provided a 'fundamental scale' for computing pair-wise comparison matrix of the criteria layers while performing an AHP (Table 5). This involves a construction of a matrix where each criterion is compared with the other criteria, relative to its importance, on a scale from 1 to 9 . Scale 1 indicates equal preference between a pair of criteria layers whereas 9 indicates a particular criteria layer is extremely favored over the other during expert judgment (Saaty 1988; Malczewski 2004).
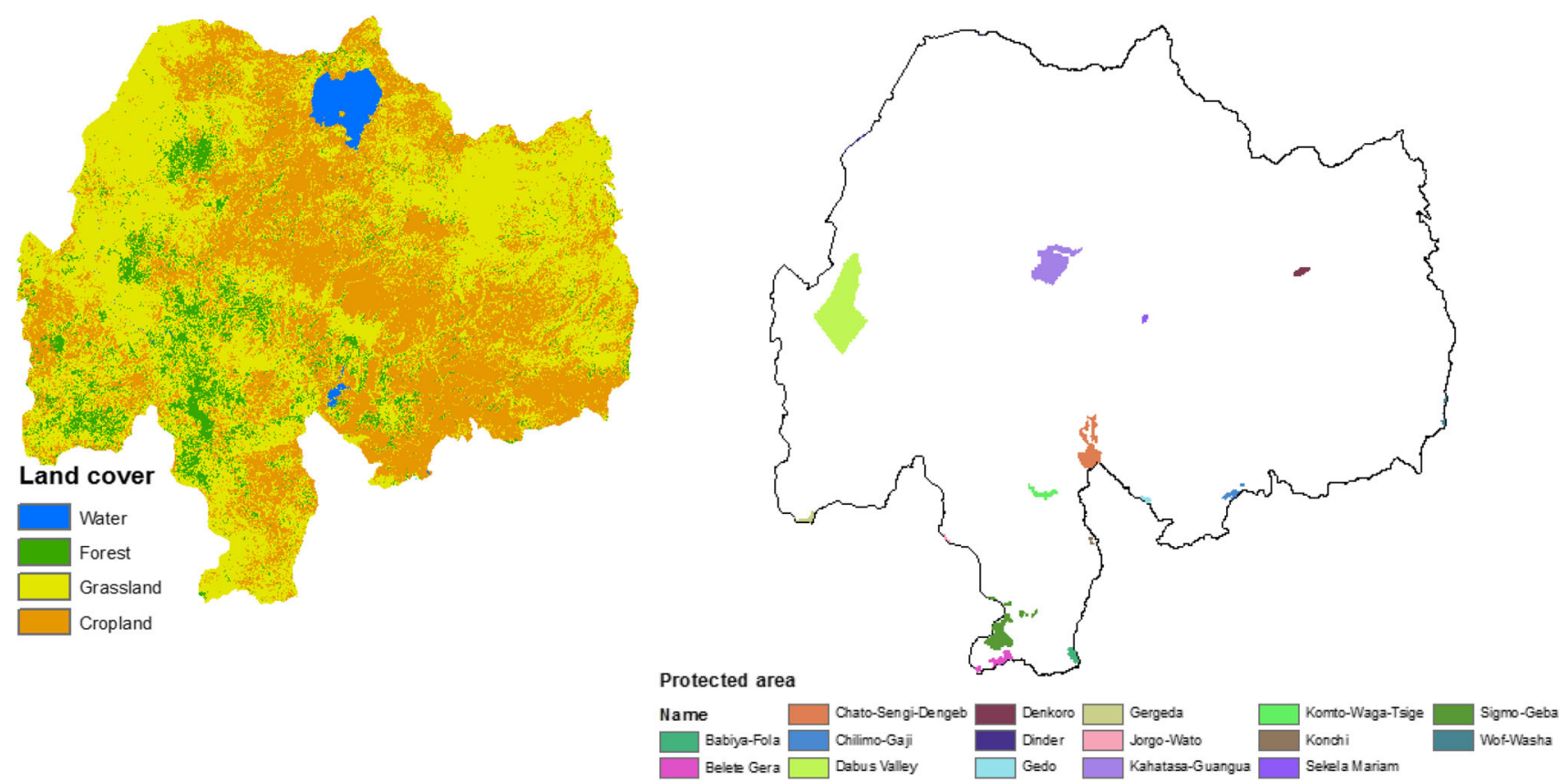

(a)

(b)

Fig. 7 a Reclassified land cover and $\mathbf{b}$ protected areas in the Abbay basin 
Fig. 8 Constraint layers. Note that constraint layers are not included in the suitability categorization but instead superimposed on the computed suitability map

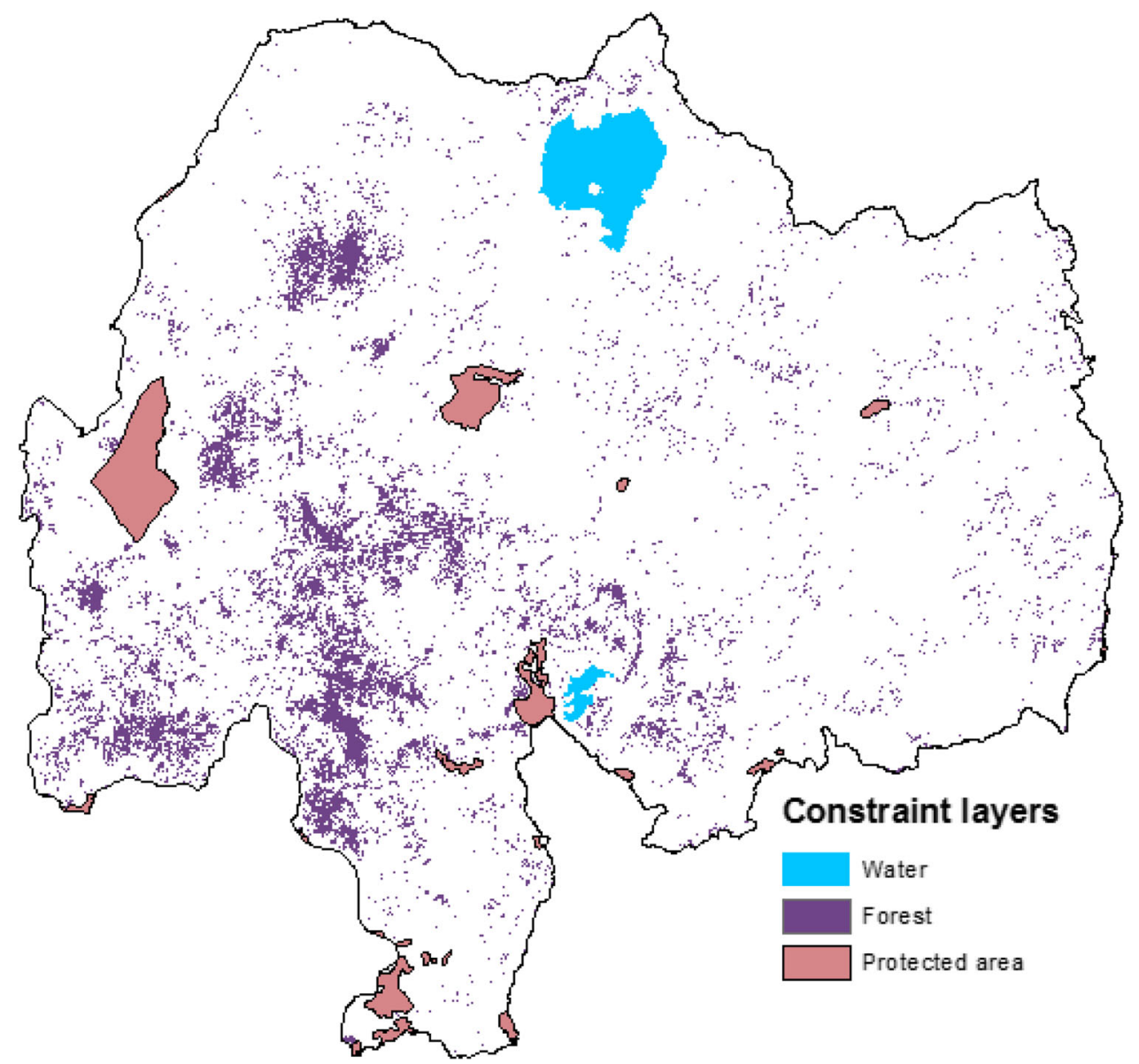

Table 5 The fundamental scale for pair-wise comparison matrix (Saaty 1980)

\begin{tabular}{lll}
\hline Relative importance & Definition & Description \\
\hline 1 & Equally important & Two criteria enrich equally to the objective \\
3 & Slightly important & Judgments and experience slightly favour one criteria over another \\
5 & Fundamentally important & Judgments and experience strongly favour one over the other \\
7 & Really important & One is strongly favoured and its dominance established in practice \\
9 & Absolutely important & Evidence favouring one criteria over another is of the highest probable order of affirmation \\
$2,4,6,8$ & Adjacent & Used when intermediate importance is needed \\
\hline
\end{tabular}

Reciprocals: If criteria $\mathrm{i}$ has one of the above numbers designated to it when compared with criteria $\mathrm{j}$, then $\mathrm{j}$ has the reciprocal value when compared with i (see Table 6)

After determining the relative importance of each criteria layer, through pair-wise comparison matrix, these values are entered on an ArcGIS based AHP tool to produce associated weights and CR value. Table 6 shows inputs for the pair-wise comparison inputs for the AHP to compute weights for the criteria layers. The weights produced from the AHP procedure using inputs in Table 6 range between 0 and 1 , where 0 denotes the least important and 1 the most important criteria determination of land suitability.
Table 7 shows various indices produced from the GIS based AHP tool. The consistency ratio $(\mathrm{CR})$ value is a function of $\mathrm{CI}$ and $\mathrm{RI}$ as defined in Eq. 3.

\section{WOA}

After computation of weights for each raster layer using AHP, weighted overlay analysis (WOA) is performed on an ArcGIS environment. Weighted overlay is an intersection of standardized and differently weighted layers during 
Table 6 Pair-wise comparison matrix for multi-criteria decision layers

\begin{tabular}{lllllllllll}
\hline Criteria layer & $\begin{array}{l}\text { Soil water } \\
\text { content }\end{array}$ & $\begin{array}{l}\text { Soil } \\
\text { stoniness }\end{array}$ & $\begin{array}{l}\text { Soil } \\
\text { type }\end{array}$ & $\begin{array}{l}\text { Dist. to } \\
\text { water }\end{array}$ & Elevation & Slope & $\begin{array}{l}\text { Soil } \\
\text { depth }\end{array}$ & $\begin{array}{l}\text { Dist. to } \\
\text { road }\end{array}$ & $\begin{array}{l}\text { Dist. to } \\
\text { town }\end{array}$ & $\begin{array}{l}\text { Criteria } \\
\text { Weight }\end{array}$ \\
\hline Soil water content & 1 & 3 & 7 & 8 & 9 & 2 & 4 & 5 & 6 \\
Soil stoniness & 0.33 & 1 & 5 & 6 & 7 & 1 & 2 & 3 & 4 & 0.307 \\
Soil type & 0.14 & 0.2 & 1 & 2 & 3 & 0.17 & 0.25 & 0.33 & 0.5 & 0.037 \\
Dist. to water & 0.13 & 0.17 & 0.5 & 1 & 2 & 0.14 & 0.2 & 0.25 & 0.33 & 0.026 \\
Elevation & 0.11 & 0.14 & 0.33 & 0.5 & 1 & 0.13 & 0.17 & 0.2 & 0.25 & 0.019 \\
Slope & 0.5 & 2 & 6 & 7 & 8 & 1 & 3 & 4 & 5 \\
Soil depth & 0.25 & 0.5 & 4 & 5 & 6 & 0.33 & 1 & 2 & 3 \\
Dist. to road & 0.2 & 0.33 & 3 & 4 & 5 & 0.25 & 0.5 & 1 & 0.218 \\
Dist. to town & 0.17 & 0.25 & 2 & 3 & 4 & 0.2 & 0.33 & 0.5 & 1 \\
\hline
\end{tabular}

Table 7 Indices computed using the GIS based AHP tool table

\begin{tabular}{ll}
\hline Index & Value \\
\hline Consistency index (CI) & 0.0495 \\
Random index (RI) & 1.46 \\
Consistency ratio (CR) & 0.0339 \\
\hline
\end{tabular}

suitability analysis (Zolekar and Bhagat 2015). The weights quantify the relative importance of the suitability criteria considered. The suitability scores assigned for the sub-criteria within each criteria layer were multiplied with the weights assigned for each criterion to calculate the final suitability map using the WOA technique (see Eq. 4).

$S=\sum_{i=1}^{n} W_{i} X_{i}$

where $S$ is the total suitability score, $W_{i}$ is the weight of the selected suitability criteria layer, $X_{\mathrm{i}}$ is the assigned subcriteria score of suitability criteria layer $i$, and $n$ is the total number of suitability criteria layer (Cengiz and Akbulak 2009; Pramanik 2016).
Fig. 9 Agricultural land suitability in the Abbay basin excluding constraint layers

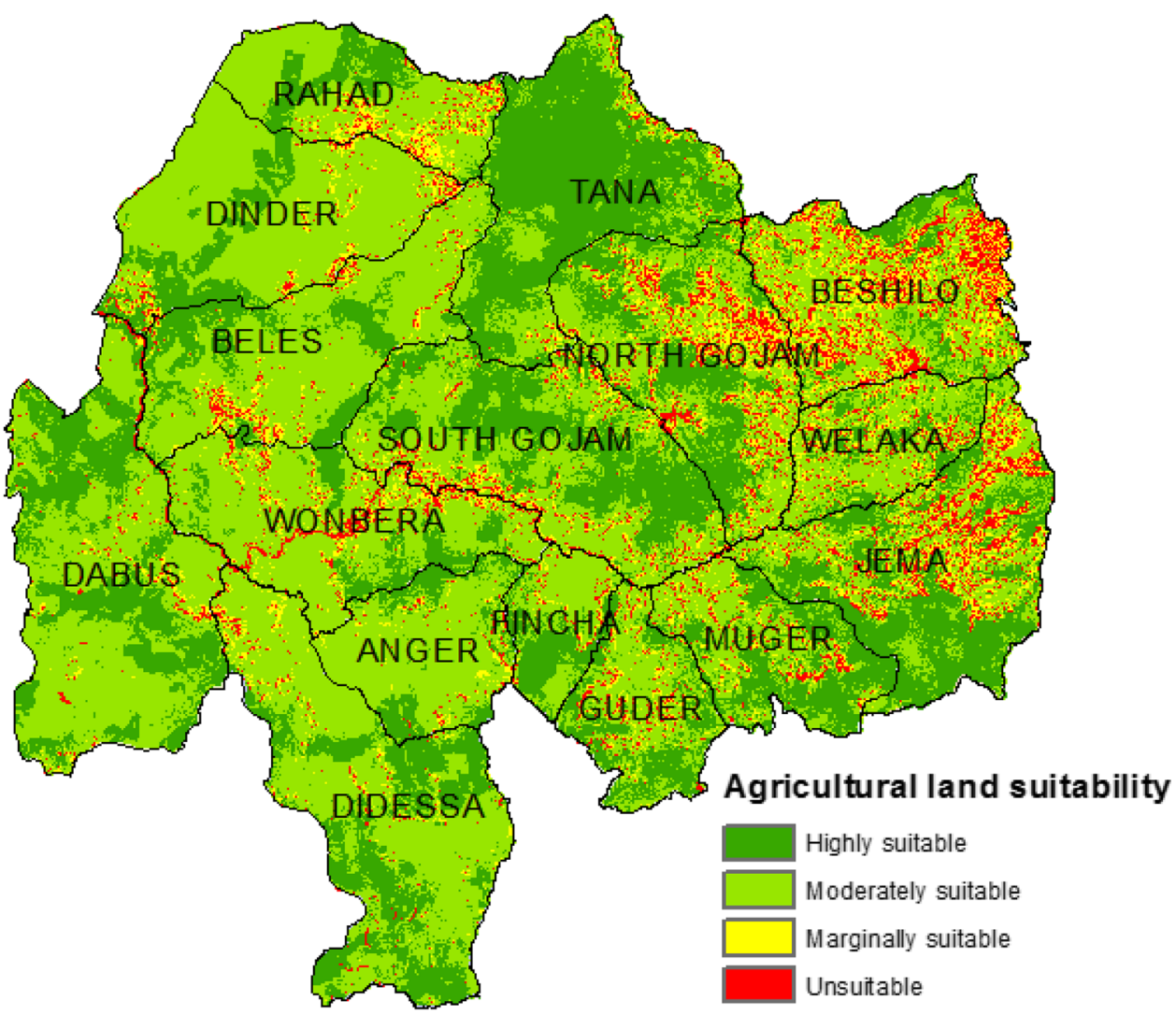




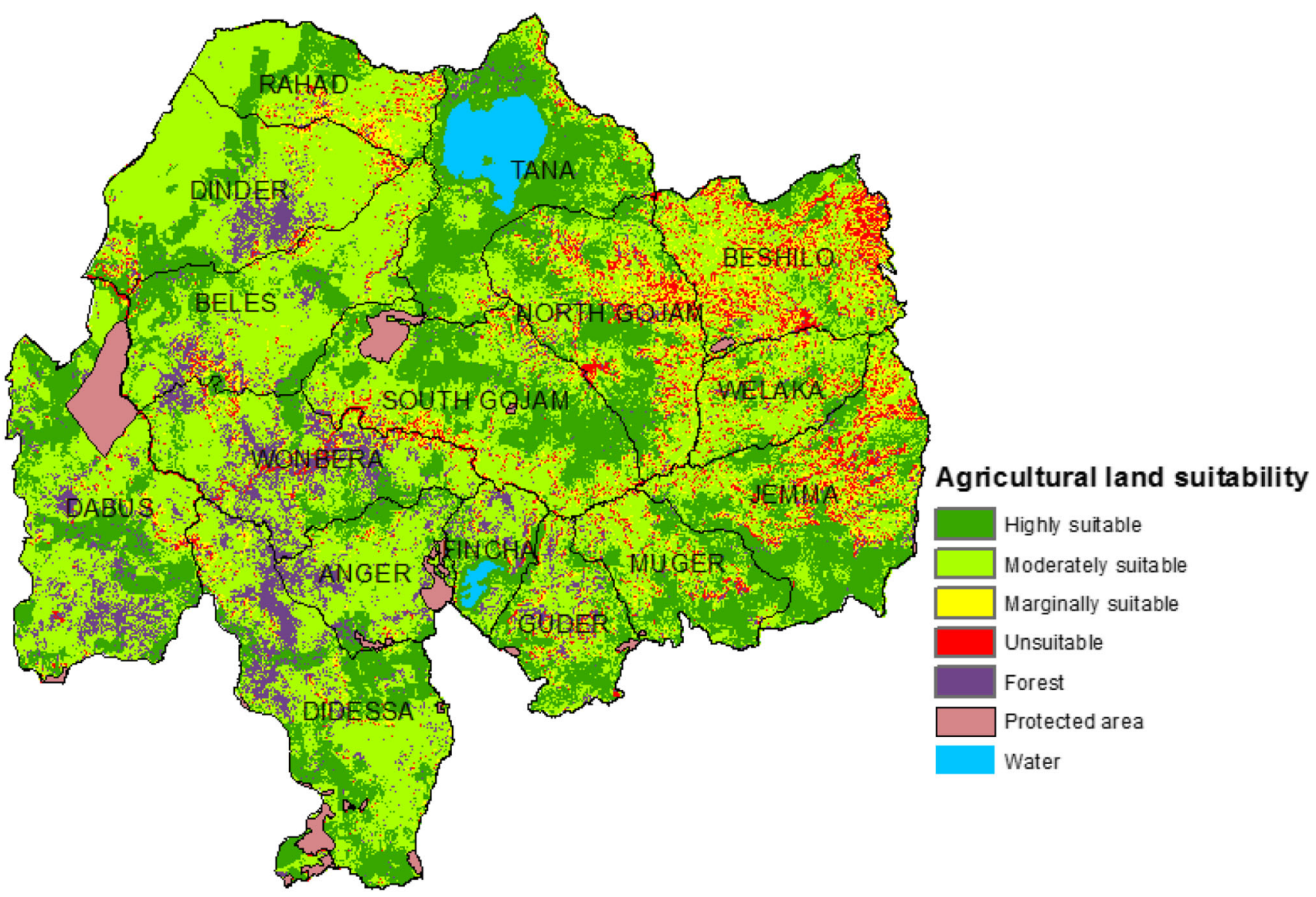

Fig. 10 Agricultural land suitability in the Abbay basin with constraint layers. The constraint layers include water bodies, forest and protected areas which were assumed to be fixed in this study

\section{Results}

The weighted overlay analysis carried out using the criteria layers with their respective weights generated a combined suitability map (Fig. 9). Forest, protected area and water bodies were then superimposed on this suitability map to determine the final suitability map (Fig. 10). According to this map, it was determined that $28.6 \%\left(57,050 \mathrm{~km}^{2}\right)$ of the study area is highly suitable, $48.9 \%\left(97,812 \mathrm{~km}^{2}\right)$ is moderately suitable, and $6.2 \%\left(12,378 \mathrm{~km}^{2}\right)$ is marginally suitable. About $6 \%$ $\left(11,978 \mathrm{~km}^{2}\right)$ is determined to be 'unsuitable' whereas the rest $10.3 \%\left(20,594 \mathrm{~km}^{2}\right)$ is determined unavailable (or currently unsuitable) categories (see Table 8).

Water bodies, forest cover and protected areas are treated as 'unavailable' or are constraints for the suitability analysis and are instead superimposed on the final suitability map (Fig. 10).

Table 9 presents details of area and percentage coverage of the different suitability categories per each catchment in the Abbay basin.
Table 8 Summary of agricultural land suitability map of the Abbay basin

\begin{tabular}{lll}
\hline Suitability & Area $\left(\mathrm{km}^{2}\right)$ & Percent $(\%$ of the basin area) \\
\hline Highly suitable & 57,050 & 28.6 \\
Moderately suitable & 97,812 & 48.9 \\
Marginally suitable & 12,378 & 6.2 \\
Unsuitable & 11,978 & 6 \\
Unavailable* & 20,594 & 10.3 \\
Total area & 199,812 & $100 \%$
\end{tabular}

* This includes protected areas, forest cover and water bodies

\section{Discussion and recommendation}

A closer look at the percentage coverage of the suitable lands with the catchments indicates very high variation in between the different catchments of the basin (see Table 9). About $50 \%$ of the Tana catchment (North), for instance, is classified as 'highly suitable' whereas as low as only $12 \%$ is classified in the same category in Beshilo 
Table 9 Summary of land suitability level for agriculture cca catchment area $\left[\mathrm{km}^{2}(\%)\right]$

\begin{tabular}{|c|c|c|c|c|c|c|c|}
\hline No. & Catchment & Total area & Highly suitable & Moderately suitable & Marginally suitable & Unsuitable & Unavailable \\
\hline 1 & Tana & 15,054 & $7535(50.1)$ & $3651(24.3)$ & $246(1.6)$ & $378(2.5)$ & $3244(21.5)$ \\
\hline 2 & North Gojam & 14,389 & 4539 (31.5) & $6164(42.8)$ & $1750(12.2)$ & $1607(11.2)$ & $329(2.3)$ \\
\hline 3 & Beshilo & 13,242 & $1582(11.9)$ & $5959(45)$ & $2526(19.1)$ & $2954(22.3)$ & $221(1.7)$ \\
\hline 4 & Welaka & 6415 & $1061(16.6)$ & $3959(61.7)$ & $722(11.3)$ & $550(8.6)$ & $113(1.8)$ \\
\hline 5 & Jema & 15,782 & $6301(39.9)$ & $5524(35)$ & $1750(11.1)$ & $1961(12.4)$ & 246 (1.6) \\
\hline 6 & South Gojam & 16,762 & $6516(38.9)$ & $7514(44.8)$ & $869(5.2)$ & 777 (4.6) & $1086(6.5)$ \\
\hline 7 & Muger & 8188 & $3573(43.6)$ & $3470(42.4)$ & $511(6.2)$ & $457(5.6)$ & $177(2.2)$ \\
\hline 8 & Guder & 7011 & $2299(32.8)$ & $3224(46)$ & $499(7.1)$ & $383(5.5)$ & $606(8.6)$ \\
\hline 9 & Fincha & 4089 & $899(22)$ & $2113(51.7)$ & $108(2.6)$ & $192(4.7)$ & 777 (19) \\
\hline 10 & Didessa & 19,630 & $6129(31.2)$ & $9761(49.7)$ & 467 (2.4) & $300(1.5)$ & $2973(15.2)$ \\
\hline 11 & Anger & 7901 & $1283(16.2)$ & $4819(61)$ & 123 (1.6) & 128 (1.6) & $1548(19.6)$ \\
\hline 12 & Wombera & 12,957 & $1892(14.6)$ & $6916(53.4)$ & $654(5)$ & $713(5.5)$ & $2782(21.5)$ \\
\hline 13 & Dabus & 21,032 & $6458(30.7)$ & 9762 (46.4) & $315(1.5)$ & 315 (1.5) & $4182(19.9)$ \\
\hline 14 & Beles & 14,200 & 2978 (21) & $9251(65.1)$ & $531(3.7)$ & 423 (3) & $1017(7.2)$ \\
\hline 15 & Dinder & 14,891 & $2344(15.7)$ & $10,419(70)$ & $521(3.5)$ & 383 (2.6) & $1224(8.2)$ \\
\hline 16 & Rahad & 8269 & $1651(20)$ & $5306(64.2)$ & 786 (9.5) & 457 (5.5) & $69(0.8)$ \\
\hline \multicolumn{3}{|c|}{ Max** } & 50.1 & 70.0 & 19.1 & 22.3 & 21.5 \\
\hline \multicolumn{3}{|l|}{ Min } & 11.9 & 24.3 & 1.5 & 1.5 & 0.8 \\
\hline \multicolumn{3}{|l|}{ Mean } & 27.3 & 50.2 & 6.5 & 6.2 & 9.9 \\
\hline \multicolumn{3}{|l|}{ SD } & 11.7 & 12.0 & 5.0 & 5.4 & 8.2 \\
\hline
\end{tabular}

* Area of the catchment in $\mathrm{km}^{2}$ and in bracket percentage area of the catchment

** Max, min, mean and SD denote maximum, minimum, mean and standard deviation statistics, respectively, of percentage of area coverage in the 16 catchments

(North-East). Similarly, there is a large variation in percentage coverage of 'moderately suitable' lands per catchment which ranges from $70 \%$ in the Dinder catchment (North-West) to about $24 \%$ in the Tana catchment. A much lower variation in percentage area between catchments is seen when considering the sum of 'highly suitable' and 'moderately suitable' categories $(\max =86 \%$; $\min =57 \%$; mean $=77 \%$; SD = 7) compared with the sum of 'marginally suitable' and 'unsuitable' lands $(\max =41 \% ; \min =3 \%$; mean $=12 ; \mathrm{SD}=10)$.

What is generally noticeable is that the North, NorthWest, South and South-West catchments of the basin seem to have larger percentage area for 'highly suitable' and 'moderately suitable' land for agriculture. On the other hand, the Western, North-Western and Central highlands of the basin seem to have higher coverage of 'marginally suitable and 'unsuitable' lands for agriculture. Looking at some of the main factors weighing into the AHP analysis such as slope, soil water content and soil stoniness, it is easy to see that the North-Western and central highlands are dominated by steep slope ranges $\left(25-80^{\circ}\right.$, Fig. 3a), low percentage of soil water content ( $22 \%$, Fig. $4 \mathrm{~b})$ and high level of soil stoniness ( $75 \%$, Fig. 5b). This part of the basin is also located on a relatively higher elevation range
(3000-4239 m a. s. 1.) than the South and South-West part of the basin. The combinations of steep slopes and higher elevation may imply a high susceptibility for land degradation and soil erosion, among other things, in the catchments in this part of the basin resulting in higher percentage of stony upper soil. It is advised that land and water managers and policy makers in the basin prioritize such areas during land and/or soil restoration efforts.

Acknowledgments This research has received funding from the European Union Seventh Framework Programme (FP7/2007-2013) through the AFROMAISON project under Grant Agreement No. 266379 .

\section{References}

Awulachew SB, Ahmed A, Haileselassie A, Yilma A, Bashar K, Mccartney M, Steenhuis T (2010) Improved water and land management in the Ethiopian highlands and its impact on downstream stakeholders dependent on the Blue Nile

Bandyopadhyay S, Jaiswal R, Hegde V, Jayaraman V (2009) Assessment of land suitability potentials for agriculture using a remote sensing and GIS based approach. Int J Remote Sens 30:879-895

Bewket W (2002) Land cover dynamics since the 1950s in Chemoga watershed, Blue Nile basin, Ethiopia. Mt Res Dev 22:263-269 
Bewket W, Sterk G (2002) Farmers' participation in soil and water conservation activities in the Chemoga watershed, Blue Nile basin, Ethiopia. Land Degrad Dev 13:189-200

Bizuwerk A, Peden D, Taddese G, Getahun Y (2005) GIS application for analysis of land suitability and determination of grazing pressure in upland of the Awash River Basin. International Livestock Research Institute (ILRI), Addis Ababa

Bojórquez-Tapia LA, Diaz-Mondragon S, Ezcurra E (2001) GISbased approach for participatory decision making and land suitability assessment. Int J Geogr Inf Sci 15:129-151

Bonfante A, Bouma J (2015) The role of soil series in quantitative land evaluation when expressing effects of climate change and crop breeding on future land use. Geoderma 259:187-195

Bontemps S, Defourny P, Bogaert EV, Arino O, Kalogirou V, Perez JR (2011) GLOBCOVER 2009-Products description and validation report

Cengiz T, Akbulak C (2009) Application of analytical hierarchy process and geographic information systems in land-use suitability evaluation: a case study of Dümrek village (Çanakkale, Turkey). Int J Sustain Dev World Ecol 16:286-294

CSA (2007) Population and Housing Census of Ethiopia [Online]. Central Statistical Agency, Addis Ababa

Dominati E, Mackay A, Bouma J, Green S (2016) An ecosystems approach to quantify soil performance for multiple outcomes: the future of land evaluation? Soil Sci Soc Am J 80(2):438-449

EEPCO (2014) Grand Ethiopian Renaissance Dam: Significance of the Abay Basin [Online]. Addis Ababa, Ethiopia. http://www. eepco.gov.et. Accessed Jan 2015

FAO (2003) Country Pasture-Forage Resource Profiles-Ethiopia [Online]. http://www.fao.org/ag/AGP/AGPC/doc/counprof/ethio pia/ethiopia.htm. Accessed Feb 2015

FAO (2013) GEONETWORK: Major soil groups of the world (FGGD). FAO, Rome

FAO (2014) FAO GEONETWORK: effective soil depth $(\mathrm{cm})$ (GeoLayer) [Online], FAO, Rome. http://data.fao.org/ref/c3bfc 940-bdc3-11db-a0f6-000d939bc5d8.html?version=1.0 Accessed Feb 2015

Gebrehiwot SG, Bewket W, Gärdenäs AI, Bishop K (2014) Forest cover change over four decades in the Blue Nile Basin, Ethiopia: comparison of three watersheds. Reg Environ Change 14:253-266

GEE. Google Earth Engine [Online]. https://earthengine.google.org/ \#intro. Accessed Jan 2016

Gorelick N (2013) Google Earth Engine. EGU General Assembly Conference Abstracts, Vienna. 11997

H Akınc1, AY Özalp, B Turgut (2013) Agricultural land use suitability analysis using GIS and AHP technique. Comput Electron Agric 97:71-82

Hurni H, Tato K, Zeleke G (2005) The implications of changes in population, land use, and land management for surface runoff in the upper Nile basin area of Ethiopia. Mt Res Dev 25:147-154

ILRI, FAO (1992) Technical paper 1: soil classification and characterization. In: Tripathl BR, Psychas PJ (eds) Alley Farming Research Network for Africa. International Livestock Centre for Africa, Addis Ababa

Juhos K, Szabó S, Ladányi M (2016) Explore the influence of soil quality on crop yield using statistically-derived pedological indicators. Ecol Ind 63:366-373

Lambin EF, Meyfroidt P (2011) Global land use change, economic globalization, and the looming land scarcity. Proc Natl Acad Sci 108:3465-3472

Malczewski J (2004) GIS-based land-use suitability analysis: a critical overview. Prog Plan 62:3-65

Marinoni O (2009) AHP 1.1-decision support tool for ArcGIS [Online]. http://arcscripts.esri.com/details.asp?dbid=13764. Accessed Feb 2015
Moore R, Hansen M (2011) Google Earth Engine: a new cloudcomputing platform for global-scale earth observation data and analysis. AGU Fall Meeting Abstracts, 02

Motuma M, Suryabhagavan K, Balakrishnan M (2016) Land suitability analysis for wheat and sorghum crops in Wogdie District, South Wollo, Ethiopia, using geospatial tools. Appl Geomat 8:57-66

Olaniyi A, Ajiboye A, Abdullah A, Ramli M, Sood A (2015) Agricultural land use suitability assessment in Malaysia. Bulg $\mathbf{J}$ Agric Sci 21:560-572

Prakash T (2003) Land suitability analysis for agricultural crops: a fuzzy multicriteria decision making approach. MS Theses, International institute for geo-information science and earth observation enschede, The Netherlands

Pramanik MK (2016) Site suitability analysis for agricultural land use of Darjeeling district using AHP and GIS techniques. Model Earth Syst Environ 2:1-22

Reshmidevi T, Eldho T, Jana R (2009) A GIS-integrated fuzzy rulebased inference system for land suitability evaluation in agricultural watersheds. Agric Syst 101:101-109

Rossiter DG (1996) A theoretical framework for land evaluation. Geoderma 72:165-190

Rudel TK, Schneider L, Uriarte M, Turner BL, Defries R, Lawrence D, Geoghegan J, Hecht S, Ickowitz A, Lambin EF (2009) Agricultural intensification and changes in cultivated areas, 1970-2005. Proc Natl Acad Sci 106:20675-20680

Saaty TL (1980) The analytic hierarchy process: planning, priority setting, resource allocation, McGraw-Hill International Book Co, New York

Saaty RW (1987) The analytic hierarchy process-what it is and how it is used. Math Model 9:161-176

Saaty TL (1988) What is the analytic hierarchy process? Springer, Berlin

Saaty TL (2008) Decision making with the analytic hierarchy process. Int J Serv Sci 1:83-98

Shalaby A, Ouma Y, Tateishi R (2006) Land suitability assessment for perennial crops using remote sensing and Geographic Information Systems: a case study in northwestern Egypt: (Bewertung der Eignung von Standorten zum Anbau von mehrjährigen Fruchtarten mittels Fernerkundung und GIS: eine Fallstudie in Nord-West Ägypten). Arch Agron Soil Sci $52: 243-261$

Sheng T (1990) Watershed management field manual. FAO conservation guide, 13

Steiner F, McSherry L, Cohen J (2000) Land suitability analysis for the upper Gila River watershed. Landsc Urban Plan 50:199-214

Teferi E, Bewket W, Uhlenbrook S, Wenninger J (2012) Understanding recent land use/cover dynamics in the source region of the Upper Blue Nile, Ethiopia: systematic and random transitions. Agric Ecosyst Environ (Submitted)

Tekleab S, Mohamed Y, Uhlenbrook S, Wenninger J (2014) Hydrologic responses to land cover change: the case of Jedeb mesoscale catchment, Abay/Upper Blue Nile basin, Ethiopia. Hydrol Process 28:5149-5161

Trabucco A, Zomer R (2010) Global soil water balance geospatial database. CGIAR Consortium for Spatial Information. CGIARCSI GeoPortal, http://cgiar-csi.org

Tscharntke T, Clough Y, Wanger TC, Jackson L, Motzke I, Perfecto I, Vandermeer J, Whitbread A (2012) Global food security, biodiversity conservation and the future of agricultural intensification. Biol Conserv 151:53-59

UNEP-WCMC (2012) The world database on protected areas (WDPA) [Online]. Cambridge, UK. http://www.protectedpla net.net/countries/68. Accessed Jan 2015

Van Orshoven J, Terres J, Toth T (2012) Updated Common biophysical criteria to define natural constraints for agriculture in Europe. Ispra. doi:10.2788/91182. http://agrienv.jrc.ec.europa.eu 
Wale A, Collick AS, Rossiter DG, Langan S, Steenhuis TS (2013) Realistic assessment of irrigation potential in the Lake Tana basin, Ethiopia

Wang F (1994) The use of artificial neural networks in a geographical information system for agricultural land-suitability assessment. Environ Plan A 26:265-284

Yalew S, Teferi E, Van Griensven A, Uhlenbrook S, Mul M, Van der Kwast J, Van der Zaag P (2012) Land use change and suitability assessment in the Upper Blue Nile basin under water resources and socio-economic constraints: a drive towards a decision support system

Zabihi H, Ahmad A, Vogeler I, Said MN, Golmohammadi M, Golein B, Nilashi M (2015) Land suitability procedure for sustainable citrus planning using the application of the analytical network process approach and GIS. Comput Electron Agric 117:114-126

Zeleke G, Hurni H (2001) Implications of land use and land cover dynamics for mountain resource degradation in the Northwestern Ethiopian highlands. Mt Res Dev 21:184-191

Zhang J, Su Y, Wu J, Liang H (2015) GIS based land suitability assessment for tobacco production using AHP and fuzzy set in Shandong province of China. Comput Electron Agric 114:202-211

Zolekar RB, Bhagat VS (2015) Multi-criteria land suitability analysis for agriculture in hilly zone: remote sensing and GIS approach. Comput Electron Agric 118:300-321 